\title{
YÜRÜRLÜKTEN KALDIRILMASI GEREKEN BİR HÜKÜM OLARAK OLAĞANÜSTÜ DURUMLARDA VE PEK ÖNEMLİ BİR SEBEPLE EVLENMEYE IZIN VERILLMESİ (TMK m. 124/II)
}

\author{
AS A PROVISION TO BE REPEALED THAT THE PERMISSION TO MARRIAGE UNDER \\ EXTRAORDINARY CIRCUMSTANCES AND VERY IMPORTANT REASONS (CC Art. 124)
}

\author{
Gülşah VARDAR HAMAMCIOĞLU* $\stackrel{m}{\square}$
}

\section{Makale Bilgi}

Gönderi: $26 / 11 / 2020$

Kabul :28/02/2021

\section{Anahtar Kelimeler}

Evlenme Yaşı,

Olağanüstü Evlenme

Yașı,

Yokluk,

Mutlak Butlan,

Cocuk,

Çocuğun Menfaati.

\section{Article Info}

Received: $26 / 11 / 2020$ Accepted: 28/02/2021

\section{Keywords}

Age of Marriage, Extraordinary Age of Marriage,

Non-Existence, Absolute Nullity, Child,

Interest of Child.

\begin{abstract}
Özet
https://dai.org/10.21492/inuhfd.831790 do

Evlenme yaşının düzenlendiği TMK m.124 uyarınca "Erkek ve kadın onyedi yaşııı doldurmadıkça evlenemez./ Ancak hâkim olağanüstü durumlarda ve pek önemli bir sebeple onaltı yaşını doldurmuş olan erkek veya kadının evlenmesine izin verebilir. Olanak bulundukça karardan önce ana ve baba veya vasi dinlenir." Bu hüküm uyarınca kadın ve erkek arasında bir ayrım söz konusu olmaksızın kişinin olağan evlenme yaşı onyedi olarak belirlenmiştir. Ancak TMK m.11 uyarınca erginlik yaşı onsekiz olarak belirlenmiş olduğundan henüz ergin olmayan küçüğün TMK m.126 uyarınca ancak yasal temsilcisinin izni ile evlenmesi mümkündür. Erginlik yaşı ile evlenme yaşının Kanun'da farklı düzenlenmesi isabetli olmayıp evlenme yaşının da erginlik yaşı olarak belirlenmesi, bu yolla evlenmeyle kazanılan erginlik kurumunun ortadan kaldırılması kanımızca en doğru yoldur. Çalışma konumuzu oluşturan hüküm ise TMK m.124/II'dir. Bu hükümde olağanüstü bir durum veya pek önemli sebebin varlığı halinde hâkimin onaltı yaşını tamamlamış küçüğün evlenmesine izin verilebileceği düzenlenmiştir. Hüküm, hem erginlik yaşı ile uyumlu olmaması hem de onaltı yaşını dolduran küçüğün evlenmesi noktasında hâkime geniş bir takdir yetkisi vermesi bakımından üzerine düşünülmesi gereken bir hükümdür. Zira yargı kararlarına bakıldığında evlenmesine izin verilmesi istenen küçük, birçok ihtimalde onaltı yaşını doldurma şartını sağlamamaktadır. $\mathrm{Bu}$ bağlamda hükmün, Anayasa'ya, ülkemizce de onaylanan Kadına Karşı Şiddetin Önlenmesi Sözleşmesine (CEDAW) ve Çocuk Hakları Sözleşmesine aykırı olduğu bir gerçektir. Bu çalışmada da TMK m.124/II hükmünün şartları, sonuçları ve yürürlükten kaldırılması gereği irdelenecek, karşılaştırmalı hukuk verilerinden de yararlanarak çocuğun üstün menfaati kavramı temelinde sonuca varılacaktır.
\end{abstract}

\begin{abstract}
In accordance with CC Art. 124: "Male/female may not get married unless she/he has completed full age of seventeen. / However, judge may give permission for marriage of male/female completed age of sixteen in extraordinary situations and for a very important reason. Father, mother or guardian are heared before decision whenever possible." With this provision minimum age of marriage is determined as seventeen without distinction between male and female. In accordance with CC Art. 11: "Majority commences on completion of age of eighteen years.". So even though she/he has reached the age of seventeen, since the person is not yet mature - she/he is minor- accordance with CC Art. 126 can only marry with the permission of its legal representative. It is not appropriate to differently regulate age of maturity and age of marriage. Our study subject is related to CC Art 124/II. In this provision it was regulated that under extraordinary situations or very important reason, the judge may give permission to marriage of male/female who have completed age of sixteen. This provision should be considered because in this provision the age of marriage and the maturity is not compatible and judge has a wide power of discretion for marriage of person who has reached age of sixteen. According to judicial decisions, person who is asked to be allowed to marry does not fulfill requirements of age of sixteen. In this context, it's fact that this provision is against the Constitution, Convention on The Elimination of All Forms of Discrimination Against Women (CEDAW), which is approved by our country and Convention on the Rights of the Child.In this study, conditions and results of the provision and the necessity of repeal will be discussed and will be concluded on basis of the child's best interests with comparative law data.
\end{abstract}




\section{GİRIŞ}

Türk Medenî Kanunu'nda ${ }^{1}$ erginlik yaşı onsekiz olarak belirlenmiş olmasına rağmen TMK m.124/I hükmünde evlenme yaşı kadın ve erkek bakımından fark söz konusu olmaksızın onyedi olarak belirlenmiştir. Ancak yine TMK m.126 uyarınca küçügün evlenmesi yasal temsilcinin iznine tâbi tutulmuş olup onyedi yaşındaki küçügü̈n evlenmesi yasal temsilcisinin izin vermesi koşuluna bağlanmıştır. Diğer yandan eMK ${ }^{2}$ m. 88 hükmü, kadın ve erkek arasında evlenme yaşı bakımından farklı bir düzenleme barındırmaktaydı. Bu hüküm uyarınca kadın onbeş, erkek onyedi yaşını doldurmakla koşuluyla yine eMK m.90 uyarınca ana ve babasının rızasıyla evlenebilmekteydi. Yürürlükten kalkan eMK m.88 hükmünde yer alan kadın ve erkek arasındaki evlenme yaşı ayrımı bir tarafa, bugün yürürlükteki TMK m.124/I hükmünün isabeti de tartışma konusudur. Zira erginlik yaşı ile evlenme yaşı arasında bu şekilde bir ikilik yaratılmasının hiçbir somut gerekçesi yoktur. Ancak bu çalışma kapsamında evlenme yaşı ile erginlik yaşı arasında yaratılmış ikilik tartışılmayacak olup TMK m.124/II hükmünde düzenlenmiş olağanüstü evlenme yaşı düzenlemesi tartış1lacaktır. TMK m.124/II uyarınca olağanüstü durumlarda ve pek önemli bir sebeple onaltı yaşını dolduran kadın veya erkeğin hâkim izni ile evlenmesi mümkün kılınmıştır. İşte bu çalışmanın yapılma amacı bu hükmün şartlarının değerlendirilmesi, şartları sağlamadan evlenmesine izin verilen kişilerin evliliklerinin akıbetinin değerlendirilmesi ve nihayetinde hükmün yürürlükten kaldırılması gereğine ilişkin görüşlerimizin ortaya konulmasıdır.

\section{TÜRK MEDENÎ KANUNU'NUN EVLENME YAŞINA İLIŞSKİN DÜZENLEMESI}

Evlenme ehliyeti ve evlenme yaşı Türk Medenî Kanunu'nda hak ehliyetinden ayrı ve farklı düzenlenmiştir. İlk olarak TMK m.124/I hükmünde evlenme için asgari bir yaş düzenlenmiş olup bu yaşın altındaki kişiler bakımından 'hak ehliyetsizliği' söz konusu olur. Diğer yandan Kanun'da fiil ehliyeti şartları ile evlenme ehliyeti de farklı düzenlenmiştir. Bilindiği üzere kişi erginse yani onsekiz yaşını doldurmuşsa, ayırt etme gücüne sahipse ve kısıtlı değilse fiil ehliyeti bakımından tam ehliyetlidir. Ancak TMK m.124/I hükmünde ayrıca evlenme erginliği düzenlenmiş olup bu hüküm uyarınca kadın veya erkeğin evlenmesi onyedi yaşını doldurmuş olmasına bağlanmıştır. Ancak kişi onyedi yaşında henüz tam ehliyetli olmayıp sınırlı ehliyetsiz olduğundan TMK m.126 gereği onyedi yaşını tamamlamış sınırlı ehliyetsizin evlenmesi yasal temsilcisinin rıza vermesine bağlanmıştır.

Mülga Medeni Kanun'un 1926 y1lında ilk yürürlüğe girdiği halinde evlenme yaşı kadın için onyedi, erkek için onsekiz olarak belirlenmişti. Ancak bu yaşın ülke gerçeğine uymaması karşısında ve özellikle yaş düzeltme davalarının artması nedeniyle ${ }^{3}$ hüküm 1938 yılında değiştirilmiş ${ }^{4}$ ve evlenme yaşı kadın için onbeş, erkek için onyedi; olağanüstü evlenme yaşı kadın için ondört, erkek için onbeş olarak belirlenmişti. Nihayet 2002 değişikliği ile bu yaş kadın ve erkek için onyedi olarak belirlenmiştir. Bu değişikliğin kadın erkek arasındaki evlenme yaşı farkını ortadan kaldırması bakımından olumlu olduğunu söylemek mümkündür. Ancak doktrinde 'olağan evlenme yaşı' olarak nitelendirilen bu yaşın erginlik yaşından neden farklı düzenlendiğini anlamak mümkün değildir. Bizce erginlik yaşından daha büyük bir yaş örneğin yirmi belki yirmibir şeklinde düzenleme yapmak gerekirken, evlenme yaşının onyedi olarak belirlenmesi isabetli olmamıştır.

Bilindiği üzere onyedi yaşındaki ve ayırt etme gücüne sahip kişi fiil ehliyeti bakımından sınırlı ehliyetsizdir ve TMK m.16 gereği bu kişinin yasal temsilcinin katılımı, izni veya icazeti olmadan geçerli hukukî işlem, daha da somutlaştırmak gerekirse borçlanma işlemi niteliğinde satış sözleşmesi yapması mümkün değildir. Kanun'un, satış sözleşmesi yaparken dahi sınırlı ehliyetsizi bu denli korumaya çalışması karşısında sınırlı ehliyetsizin yasal temsilci rızasıyla evlenmesini mümkün kılması bizce çelişki barındırmaktadır. Ancak tekrar belirtelim bu çalışmanın yapılma amacı, olağan evlenme yaşının erginlik yaşından farklı düzenlenmiş olmasının isabetsizliğini değil TMK m.124/II hükmünde düzenlenmiş olan ve doktrinde olağanüstü evlenme yaşı olarak adlandırılan kurumun isabetsizliğini irdelemektir.

\footnotetext{
${ }^{1}$ RG. 08.12.2001/24607.

${ }^{2}$ RG. 04.04.1926/339.

${ }^{3}$ NAMLI, Mert: "Yeni Medenî Kanunun Evlilik Hukukunda Yaptığı Değişiklikler”, Galatasaray Üniversitesi Hukuk Fakültesi Dergisi, 2(2), 2003, s.257.

${ }^{4}$ RG. 28.6.1938/3945.
} 
Belirtelim ki İsviçre Hukuku'nda bu düzenlemeye karş1lık gelen İsMK m.94'ün ikinci fikras1 1.1.2013 tarihinde yürürlüğe giren yasa ile yürürlükten kaldırılmış olup, bu hukuk sisteminde ancak onsekiz yaşını tamamlayanların evlenmesi mümkündür ${ }^{5}$. Yine aynı tarihli değişiklikle İsMK m.105 hükmüne ek yapılarak onsekiz yaşın altındaki evliliklerin mutlak butlan yaptırımına tabi olduğu da düzenlenmiştir.

\section{OLAĞANÜSTÜ EVLENME YAŞI}

\section{A. Genel Olarak}

Olağanüstü6 evlenme yaşını düzenleyen TMK m.124/II uyarınca: "Ancak hâkim olağanüstü durumlarda ve pek önemli bir sebeple onaltı yaşını doldurmuş olan erkek veya kadının evlenmesine izin verebilir. Olanak bulundukça karardan önce ana ve baba veya vasi dinlenir."

Görüldügü üzere bu hükümde, kişinin onaltı yaşını doldurması ve evlenmesine izin verilmesi bakımından olağanüstü durum ve pek önemli sebebin varlığı halinde hâkimin, evlenmeye izin verebileceği düzenlenmiştir.

eMK m.88/II hükmünde fevkalade hallerde ve pek mühim bir sebebin varlığı halinde onbeş yaşını dolduran erkeğin veya ondört yaşını dolduran kadının evlenmesine izin verebileceği düzenlenmişken, 2002 değişikliği ile kadın erkek bakımından bu yaş farkının ortadan kaldırılması ve yükseltilmesi elbette olumludur. Ancak 2002 yılında ve bugün 2020 yılında halen bu hükmün Kanun'da yer alıyor olmasının isabeti tartışılmalıdır ki devam eden açıklamalarımızda biz, hükmün yürürlükten kaldırılması gerektiğini savunacağız. Diğer yandan eMK m.88/II hükmünde yasal temsilcinin hâkim izninden önce dinlenmesi zorunlu iken bundan farklı olarak 2002 değişikliği ile bu husus zorunlu olmaktan çıkarılmış ve imkân varsa yasal temsilcinin dinlenmesi gereği düzenlenmiştir.

Olağanüstü evlenme yaşı özellikle eMK'nın yürürlükte olduğu dönmede doktrinde bazı yazarlarca 'kazâ̂ evlenme erginliği' ya da 'yargısal evlenme rüstü' olarak adlandırılmaktaydı'. Ancak bu şekilde bir nitelendirme kanımızca yanlış anlaşılmaya müsaitti. Zira TMK m.124/II uyarınca evlenmesine izin istenen kişi ergin sayllarak, onun evlenmesine izin verilmemekte, ancak belirli bir kişiyle evlenmesine izin verilmektedir. Dolayısıyla mahkemeden evlenme izni alan kişi dilediği kişiyle evlenmesi söz konusu değildir ${ }^{8}$. Örneğin mahkeme onaltı yaşındaki A'nın B ile evlenmesine izin vermektedir yoksa evlenme izninden sonra ve fakat evlenmeden önce B ölse A, bu izinle B'nin erkek kardeşi C ile evlenemeyecektir.

\section{B. Evlenmeye İzin Verilmesi Şartları}

TMK m.124/II hükmü incelendiğinde iki şartın zorunlu, bir şartın ihtiyarî şart olarak düzenlenmiş olduğu görülmektedir. Buna göre; evlenme başvurusunda bulunan kişi onaltı yaşını doldurmuş olmalıdır, evlenme izni için olağanüstü sebep ve pek önemli sebep bulunmalıdır ve olanak bulundukça karardan önce anne ve baba veya vasi dinlenmelidir.

Doktrinde Kanun'da sayılan bu şartlar yanında evlenmesine izin verilmesi istenen kişinin evlenme olgunluğuna erişmiş olmasının da zorunlu şart olduğu ileri sürülmektedir. Zira bu görüşe göre kişi onaltı yaşını doldurmuş olsa ve olağanüstü sebep ve pek önemli sebep bulunsa da evlenme olgunluğuna erişmemiş ise evlenmesine izin verilmemelidir 9 .

Tekrar belirtelim ki biz, hükmün yürürlükten kaldırılması gerektiğini savunacağımızdan aşağıda hükmün şartlarını incelerken de en azından hüküm yürürlükten kaldırılana kadar

\footnotetext{
${ }^{5} \mathrm{Bu}$ değișikliğin Türk Hukuku'nda yapılmamış olmasının isabetli olduğu yönünde bkz. HATEMİ, Hüseyin: Aile Hukuku, İstanbul 2020, § 4, N. 4; Ayrıca bkz. HEINRICH, Honsell/VOGT, Nedim Peter/GEISER, Thomas (Herausgeber): Basler Kommentar, Zivilgezetzbuch I, Art. 1-456, Basel 2014, Art. 94, N. 2.

${ }^{6} \mathrm{Bu}$ tabir yerine istisnaî evlenme yaşı tabirinin kullanılması gerektiği yönünde NAMLI, GÜHFD 2003, s.261.

${ }^{7}$ SCHWARZ, Andreas: Aile Hukuku, Çev. Bülent DAVRAN, İstanbul 1946, s.63; SAYMEN, Ferit Hakkı/ELBİR, Halid Kemal: Türk Medenî Hukuku, C. III, Aile Hukuku, İstanbul 1960, s.77; VELİDEDEOĞLU, Hıfzı Veldet: Türk Medenî Hukuku, C. II, Aile Hukuku, İstanbul 1965, s.58; FEYZİOĞLU, Feyzi: Aile Hukuku, İstanbul 1986, s.140; TEKİNAY, Selahattin Sulhi: Türk Aile Hukuku, İstanbul 1982, s.71; AKINTÜRK, Turgut/ATEŞ KARAMAN, Derya: Türk Medenî Hukuku, Aile Hukuku, II. Cilt, İstanbul 2020, s.66.

${ }^{8}$ DURAL, Mustafa/ÖĞÜZ, Tufan/GÜMÜŞ, Mustafa Alper: Türk Özel Hukuku, Cilt III: Aile Hukuku, İstanbul 2020, N. 254.

9 VELİDEDEOĞLU, s.60; ÖZTAN, Bilge: Aile Hukuku, Ankara 2015, s.134; TÜZÜNER, Özlem: “Onaltı Yaşını Doldurmuş Kişinin Evlenmesine İzin Verilmesi”, İstanbul Kültür Üniversitesi Hukuk Fakültesi Dergisi, (11), 2012, s.15 (Yazar, olağanüstü hal ve pek önemli sebebin objektif, evlenme olgunluğuna erişmiş olmanın sübjektif şart niteliğinde olduğunu belirtmiştir. A.e. s.12).
} 
uygulanmasını çok istisnaî hallerle sınırlı tutmak amacıyla çocuğun üstün menfaatini gözeterek dar yorum yapmayı tercih edeceğiz.

\section{Zorunlu Şartlar}

\section{a. Onaltı Yaşını Doldurmuş Olma}

TMK m.124/II hükmünde olağanüstü evlenme yaşı onaltı olarak belirlenmiştir. Bundan kasıt elbette kadın veya erkeğin onaltı yaşını doldurmuş olmasıdır. Olağan evlenme yaşının erginlik yaşından farklı düzenlenmiş olması dahi isabetli değilken onaltı yaşındaki kişinin hâkim izni ile bile olsa evlenmesine izin verilmesi kanımızca isabetli değildir.

Nitekim ulaşılan Yargitay kararlarının çok büyük çoğunluğunda Yargitay'ın yerel mahkeme kararlarını bozma gerekçesinin onaltı yaşını doldurma şartının sağlanmaması olduğu görülmüştür ${ }^{10}$. Aslında evlenme izni talebi halinde hâkimin, ilk incelemesi gereken zorunlu şart, evlenmesine izin verilecek kişinin onaltı yaş şartını sağlayıp sağlamadığı hususu iken, bu şartın sağlanmaması nedeniyle Yargıtay nezdinde bu kadar fazla sayıda karara rastlanması gerçekten üzücüdür.

\section{b. Olağanüstü Durum veya Pek Önemli Sebebin Varlığ1}

Hâkim tarafından evlenme izni verilebilmesi için erkek veya kadının onaltı yaşını doldurmuş olması yeterli değildir aynı zamanda bu kişinin evlenmesini zorunlu kılan bir durumun varlığ 1 gereklidir. Evlenmeyi zorunlu k1lan bu durum TMK m.124/II hükmünde 'olağanüstü durumlar ve pek önemli sebep' olarak ifade edilmiştir. Lafzî yorum yaptığımızda olağanüstü durumların tek başına evlenme izni için yeterli olmadığı, bu olağanüstü durumlara pek önemli sebebin eklenmesi gerektiği sonucuna varılmaktadır. Zira hükümde ' $v e$ ' bağlacı kullanılmıştır'11. Aslında olağanüstü durumun nasıl cereyan edeceği veya pek önemli sebebin nasıl cereyan edeceği hususunda somut örnek yoktur. Başka bir anlatımla iki durumu birbirinden somutlaştırarak ayırmak mümkün değildir. Dolayısıyla hem eMK m.88 hem TMK m.124 hükümlerinde ' $v e$ ' bağlacının kullanılma amacı olağanüstü durumun ve pek önemli sebebin farklı şekillerde tezahür edebileceği ihtimali değil evlenmeye izin kararı verecek hâkimin gerçekten çok istisnaî, zorunlu hallerde evlenmeye izin verebileceğini vurgulamaktır. Keza amaçsal yorum da bu kabulü desteklemektedir.

Nitekim TEKİNAY, eMK m.88 hükmünün yürürlükte olduğu sırada fevkalade hal ve pek mühim sebebin birbirine eklenmesi gereken iki ayrı şart gibi anlaşılmaması gerektiğini, hükmün 'önemli sebebin varlı̆ğ halinde istisnầ olarak' ifadesi ile kaleme alınması gerektiğini belirtmiştir ${ }^{12}$.

Birçok Yargıtay kararında olağanüstü durum veya pek önemli sebebin ne şekilde ortaya çıktığı tespit edilememiştir. Zira Yargıtay tarafından bozulan ilk derece mahkemelerinin kararlarının büyük çoğunluğunda bozulma sebebi onaltı yaşını doldurma şartının sağlanmamış olmasıdır. Dolayısıyla Yargıtay aşamasındaki kararda olağanüstü durum ve pek önemli sebebin varlığ 1 ya da yokluğu irdelemesine gerek olmadan yerel mahkeme kararları bozulmuştur ${ }^{13}$.

Doktrinde erkeğin ölüm tehlikesi içinde bulunması, nişanlı kadının öksüz, bakımsız ve yoksul olması, evlenen kadının evlenmekle anne ve babasına yardım edebilecek duruma gelmesi, kadının hamile olması, kadının evlendikten sonra evlenme yaşının daha küçük olduğu bir ülkeye gidecek olması olağanüstü durum ve pek önemli sebebe örnek olarak verilmektedir ${ }^{14}$.

Yargıtay eski tarihli bir içtihadı birleştirme kararına konu olayda küçüğün hamile kalmasının evlenme izni vermek bakımından pek önemli sebep teşkil ettiği sonucuna varmış, ancak pek önemli sebebin salt kadının hamileliğine inhisar ettirilmemesi gerektiğini belirtmiştir ${ }^{15}$. Yine doktrinde nişanlılardan birinin ölüm tehlikesi içinde olması, kadının ana ve babasını

\footnotetext{
10 Yargitay 2. HD, E. 2013/20482, K. 2014/5005, T. 10.3.2014; E. 2012/7078, K. 2013/7749, T. 21.3.2013; E. 2011/16683, K. 2012/29409, T. 6.12.2012, E. 2010/3710, K. 2011/5584, T. 30.3.2011 (www.kazanci.com).

${ }^{11}$ Burada 'veya' bağlacının kullanılması gerektiği ve dar yorumlanması gerektiği yönünde NAMLI, GÜHFD 2003, s.262, 265.

12 TEKINAY, s.77.

${ }^{13}$ Bkz. dn. 11'de anılan kararlar.

${ }^{14}$ SCHWARZ, s.63; VELIDEDEOĞLU, s.59; SAYMEN/ELBİR, s.78; ZEVKLILER, Aydın: Giriş ve Başlangıç Hükümleri, Kişiler Hukuku, Aile Hukuku, Ankara 1992, s.686; AKINTÜRK/KARAMAN, s.67, 68; DURAL/ÖĞÜZ/GÜMÜŞ, N. 257; ÖZTAN, s.134; KILIÇOĞLU, Ahmet: Aile Hukuku, Ankara 2019, s.47.

${ }^{15}$ Yargitay İçtihadı Birleştirme Kararı, E. 1935/103, K. 1935/15, T. 7.6.1935; Dar yorumlanması ve çok istisnai hallerde mümkün kabul edilmesi gerektiği yönünde bkz. SUNGURTEKİN ÖZKAN, Meral: "Erken Yaşta Evliliklerin Önlenmesi Konusunda Yargının Üstlenebileceği Rol”, Journal of Yasar University, 8(Özel Sayı), 2013, s.2188.
} 
kaybetmiş olması, kadının kaçırılmış ve ırzına geçilmiş olması, karı koca gibi birlikte yaşama, evlilik dışı ilişki için ağır baskının olduğu yörede cinsel ilişkinin gerçekleşmiş olması, seksüel nevrasteni hastalığı, erkeğin küçük yaşta kişiyle cinsel ilişkiye girme suçundan hakkında ceza soruşturması açılmış ya da tutuklanmış olması olağanüstü durum ve pek önemli sebep örnekleri arasında sayılmaktadır ${ }^{16}$.

Konuya ilişkin olarak Yargıtay 2. HD, E. 1986/4269, K. 1986/4463, T. 28.4.1986 sayıl1 kararında aynen: “... Davaya konu küçüğün nişanlısının Almanya'da çalışması ve evlenme halinde onun da Almanya'ya gidebilme imkânı elde etmesi hali Medeni Kanunun öngördüğü fevkalade bir hal ve pek önemli bir sebep olarak kabul edilemez..." şeklinde hüküm kurmuştur.

Yargitay 2. HD, E. 1986/10310; K. 1986/10529; T. 1.12 .1986 kararında aynen “... Toplanan delillerden, (H)'nin dava tarihinde 14 yaşını bitirip 15 yaşını bitirmediği, kızlığını 10 gün kadar önce kaybettiği ve (M.C) isimli şahısla kaçarak birlikte karı koca gibi yaşamağa başladiğl gerçekleşmiştir. Bu durum fevkalade hal ve pek mühim bir sebep teşkil eder. Verilecek izin, kızın aile birliği kurmasına yardım edeceği gibi ihlal olunan aile haysiyetini de telafi edecektir..." şeklinde hüküm kurmuştur.

Yine 2. HD, E. 1984/10854, K. 1985/174, T. 15.1.1985 kararında evlenme izni talep eden tarafın kızı kaçırmış olması ve hakkında hürriyeti tahdit suçundan kaynaklı soruşturma başlamış olması evlenme izni vermek bakımından yeterli kabul edilmiştir ${ }^{17}$.

Yargitay 2. HD, E. 1993/13185, K.1993/504, T. 28.1.1993 say1lı kararında baba tarafindan açılmış davada evlenme izni talep edilen kızın kaçırılma olasılığının olağanüstü hal olduğunu ve bu durumun ispatlanması halinde evlenmeye izin verilmesi gerektiği sonucuna varılmıştır.

Yargitay 2. HD, E. 2003/7198, K. 2003/8271, T. 5.6.2003 say1lı kararında aynen şu ifadeleri kullanmıştır: “... Evlenmesine izin istenen Ç. 3.4.1987 doğumlu olup vesayet altındadır. Akrabalarl tarafindan baklmakta, düzenli bir aile yaşam bulunmamaktadır. Bu durum Türk Medeni Kanunun düzenlediği 124/2. maddesine uygun pek önemli bir sebeptir. Davacı bir an önce evlenerek başkalarının yardımına bağımlı olmaktan kurtulacaktır..."

Daha yeni tarihli kararlarında Yargıtay'ın daha sıkı şartlarda evlenme izni verdiği görülmektedir. Örneği 2. HD, E. 2015/3626, K. 2015/9331, T. 6.5.2015 sayılı kararında şu ifadeleri kullanarak tarafların birlikte yaşamalarının tek başına olağanüstü durum niteliğinde olmayacağı sonucuna varmıştır: “... Tarafların birlikte olup, karı koca gibi yaşamalarının, 4721 Sayılı Türk Medeni Kanununun 124. maddesinde de belirtilen olağanüstü durum olarak kabulüne imkân bulunmamaktadır. Bu yön gözetilmeden, yazılı şekilde evlenmeye izin verilmesi doğru görülmemiştir...”

Ancak bu karara karşı kaleme alınan karşı oy yazısı ilginçtir. Bu kararda aynen şu ifadeler yer almaktadır: “... tanık beyanlarına göre küçük A. ile, S.Ö.'nün bir buçuk aydır birlikte yaşadıkları anlaşılmaktadır. Değerli çoğunluk, tarafların karı koca gibi birlikte yaşamalarını, pek önemli bir neden olarak görmemiştir... Nikâh tarafların hak ve yükümlülüklerini güvence altına alan bir kurumdur. Fiili beraberliğin nikâhla güvence altına alınmaması durumunda, küçük A'nın nafaka, tazminat ve mirasçılık hakları gibi haklarını güvence altına alacak hiçbir yasal düzenleme bulunmamaktadır. Küçügüun yaşı dolduğunda, nikâhtan kaçınabilecek karşı tarafi, küçükle nikâh yapmaya zorlayabilecek hiçbir yasal olanak da mevcut değildir. Küçüğün evlenmesine izin verilmemesi durumunda küçügün telafisi mümkün olmayan ağır zararla karşılaşması söz konusu olacaktır. Fiilen S.Ö. ile karı koca hayatı yaşayan küçük A.'nın evlenmesine izin verilmesi halinde; ne küçük, ne ailesi, ne de toplum hiçbir zarar görmeyecektir. Çă̆daş hukuk anlayışı hak ve özgürlüklerin genişletilmesi esasına dayanır. Çağdaş ülkeler, evlilikleri teşvik etmekte, fiili beraberlikleri hukukî koruma altına alan düzenlemeler yapmakta, hatta ilgili mercilere bildirilen fiili beraberliklere, evliliğe yakın hak ve hukukî korumalar sağlamaktadırlar... TMK'nın 124. maddesinin aradığı asgari yaş sınırını dolduran küçük A'nın

\footnotetext{
${ }^{16}$ DURAL/ÖĞÜZ/GÜMÜŞ, N. 257.

${ }^{17}$ Mülga 765 sayılı Ceza Kanunu (RG. 13.3.1926/320) m.434 hükmü “...kaçırllan veya alıkonulan kız veya kadın ile maznun veya mahkûmlardan biri arasında evlenme vukuunda koca hakkında hukuku amme davası ve hüküm verilmiş ise cezanın çektirilmesi tecil olunur" ş̧eklindeyken, bu hüküm Anayasa Mahkemesi tarafindan 2004 yılında (AYM.E. 2001/478, K. 2004/38, T. 25.3.2004) iptal edilmiştir. Devamında 5237 sayılı Türk Ceza Kanunu'nda (RG. 12.10.2004/25611) cinsel dokunulmazlığa karşı işlenen suçlar arasında bu hükme yer verilmemiştir. Dolayısıyla eTCK m.434 hükmünün yürürlükte kaldığı sırada Yargıtay kararlarına konu olmuş bazı olaylarda, erkek hakkında soruşturma başlatılması olağanüstü sebep olarak kabul edilmiş ve evlenmeye izin verilmiştir.
} 
fiilen birlikte yaşadığ S.Ö. ile evlenmesine izin verilmesi, hukuka ve çağdaş uygulamalara da uygundur..."

Söz konusu karşı oy yazısı hakkında eleştiri yapmaya gerek olmadığını düşünmekle birlikte, olağanüstü ve pek önemli sebebin varlığ 1 veya yokluğu konusunda takdir hâkime (TMK m.4) aittir ancak bugün evlenmeye izin verilmesi bakımından kadının hamile kalması, kadın ve erkeğin birlikte yaşıyor olması gibi olguların tek başına yeterli şart olarak kabul edilmemesi gerektiği açıktır.

\section{c. Evlenme Olgunluğuna Erişmenin Zorunlu Şart Olup Olmadığı}

TMK m.124/II hükmünden açıkça anlaşılmasa da bazı yazarlara göre hâkim evlenme izni vermeden önce aynı zamanda kişinin evlenme olgunluğuna erişmiş olup olmadığını da değerlendirmeli ve kişinin bu olgunluğa erişmediği kanaatine varırsa evlenmeye izin vermemelidir.

Kanımızca bu yönde bir şarta ihtiyaç yoktur. Zira hüküm '...hâkim... izin verebilir...' şeklinde düzenlenmiştir. Dolayısıyla hâkime zaten şartlar mevcut olsa da evlenme izni vermeme yönünde takdir yetkisi verilmiştir. Hâkimin sahip olduğu takdir yetkisinin ise "kişinin evlenme olgunluğuna erişmiş olup olmadı̆̆ ' olgusu ile sınırlamaya gerek yoktur. Örneğin onaltı yaşını doldurmuş ve yirmi yaşındaki erkek arkadaşından hamile kalmış kadın bakımından olağanüstü hal ve pek önemli sebep şartının da varlığı ile evlenme izni karar verilebilir. İki zorunlu şart yanına bir de 'evlenme olgunluğuna erişme' şartı eklendiğinde hâkim adli tıptan alınacak raporla evlenme izni verebilecektir. Bu defa evlenme izni bakımından üç zorunlu şartın da tamamlanmış olduğu, evlenmeye izin verilmesi gerektiği düşünülebilecektir. Ancak belirtelim ki önemli olan ve hâkim tarafından nazara alınması gereken husus evlenme olgunluğuna erişme değil çocuğun menfaatidir. Hâkimin ergin olmayan bir kişi hakkında karar verirken nazara alacağı husus, her zaman çocuğun menfaatidir. Çocuğun üstün menfaati, çocukla ilgili tüm iş ve davalarda temel alınması gereken kıstastır ${ }^{18}$ ve TMK m.124/II özelinde ayrıca bir zorunlu şart aramanın gereği yoktur. Çocuğun üstün menfaatini gözetilmesi ise Kanun'da ayrıca belirtilmesine gerek olmayan hukuk ilkesi niteliğini haizdir ${ }^{19}$. Evlenme olgunluğuna erişme şartı bu hükümde düzenlenmiş değildir ve hükme bu şekilde bir zorunlu şartın eklenmesi hâkimin takdir yetkisini doğru kullanmaması sonucunu doğurarak gözetilmesi gereken çocuğun üstün menfaatini değersizleştirebilecektir.

\section{2. İhtiyarî Şart: Ana, Baba veya Vasinin Dinlenmesi}

eMK m.88 uyarınca hâkimin evlenme izni kararından önce ana, baba veya vasiyi dinlenmesi zorunlu şart olarak düzenlenmişken, TMK m.124 hükmünde olanak varsa bu kişilerin dinleneceği düzenlenmiştir ${ }^{20}$.

Hükmün değişiklik gerekçesinde ${ }^{21}$ ana ve babanın bulunmaması, nerede olduklarının bilinmemesi gibi hâllerin erken evlenmeye izin verilmesini engellediği, bu nedenle bu kişilerin dinlenmesinin mutlak bir zorunluluk olmaktan çıkarılmış olduğu belirtilmiştir.

Önemle vurgulayalım ki gerek mülga hükümde gerekse de yürürlükteki hükümde sadece 'yasal temsilcinin dinlenmesi' düzenlenmiş olup yasal temsilcinin küçük adına başvurması ya da evlenmeye izin vermesi düzenlenmiş değildir.

\section{Evlenmeye İzin Verilmesi Talebinin Niteliği ve Talebe Hakkı Olana Kişiler}

\section{Talebin Niteliği}

HMK $^{22}$ m.382/(2)-b bendinde Aile Hukuku'ndaki çekişmesiz yarg1 işleri altında henüz evlenme yaşında olmayanların evlenmesine izin verilmesi çekişmesiz yargı işlerinden

\footnotetext{
18 YÜKSEL, Sera Reyhani: “Türk Medenî Kanunu'ndaki Evlenme Yaşına İlişkin Düzenlemenin Çocuk Hakları Açısından Değerlendirilmesi”, Hukuk ve Adalet Dergisi, 7(17), 2015, s.32; Özge Yücel, "Çocuğun Yüksek (Üstün) yararı Bağlamında Çocuğun İradesi”, Ufuk Üniversitesi Hukuk Fakültesi Dergisi, (3), 2013, s.118 vd.

${ }^{19} \mathrm{Bu}$ kıstasın pozitif hukuka yansımaları için ayrıca bkz. YÜCEL, UÜHFD 2013, s.125 vd.

${ }^{20} \mathrm{eMK}$ m.88 hükmünün yürürlükte olduğu sırada var olan tartışmalardan biri de hükümde anne ve babanın izninin mi yoksa sadece dinlenmesinin gerektiği idi. Zira bu hükme karș1lık gelen İsviçre Medenî Kanunun ana ve babanın dinlenmesi değil ana ve babanın muvafakatinin zorunlu olduğu düzenlenmişti. Bu farklılıktan hareketle, eMK m.88'in de ana ve babanın muvafakati şeklinde anlaşılması gerektiği ileri sürülmekteydi (SCHWARZ, s.64); Aksi yönde VELIDEDEOĞLU, s.61; SAYMEN/ELBİR, s.79; TEKINAY, s.78.

${ }^{21}$ RG. 8.12.2001/24607.

${ }^{22}$ RG. 4.2.2011/27836.
} 
sayılmıştır ${ }^{23}$. Dolayısıyla evlenmeye izin verilmesi talebinde davacı ve davalı taraf bulunmamaktadır. Nitekim evlenmeye izin verilmesi talebinde uyuşmazlık ve hak ihlali söz konusu olmadığından, salt bir hukuk kuralının uygulanmasını gerektiren iş söz konusu olduğundan burada teknik anlamda bir davadan söz etmek mümkün değildir. Bu yargılama faaliyetinde davalı da olmadığından tek taraflı bir yargılama söz konusu olur ve bu nedenle yargılamada taraf değil 'ilgili' kavramı kullanılması daha doğru olur.

Çekişmesiz yargı işlerinden HMK m.383 gereği görevli mahkeme aksine bir düzenleme bulunmadığı sürece sulh hukuk mahkemesidir. Yine HMK m.384 gereği Kanun' da aksine hüküm bulunmadıkça talepte bulunan kişinin veya ilgililerden birinin oturduğu yer mahkemesi görevlidir. Ancak Aile Mahkemelerinin Kuruluş, Görev ve Yargilama Usullerine Dair Kanun'un ${ }^{24} 4$. Maddesi uyarınca evlenme izni taleplerinde görevli mahkeme aile mahkemesi olup yetkili mahkeme evlenme izni talebinde bulunan kişinin yerleşim yeri mahkemesidir.

2. Evleneme İzni Talep Edebilecek İlgililer

a. Küçük

Evlenmeye izin talebi kişiye sıkı sıkıya bağlı hak olduğundan kişi, onaltı yaşını doldurduğunda henüz sınırlı ehliyetsiz olsa da izin için mahkemeye tek başına başvurabilir. Zira TMK m.16 uyarınca kişiye sıkı sıkıya bağlı hakların kullanılmasında yasal temsilcinin rızasına ihtiyaç olmadığı gibi TMK m.124/II uyarınca yasal temsilcinin iznine de gerek olmadığından, ergin olmayan ve fakat ayırt etme gücüne sahip küçüğün evlenme izni için tek başına başvurması mümkündür. HMK m.50 uyarınca medenî haklardan yararlanma ehliyetine sahip olan herkes davada taraf olma ehliyetine sahip olduğundan, onaltı yaşını tamamlamış küçüğün dava ehliyetine sahip olduğu tartışmasızdır. Dava ehliyeti ise HMK m.51 hükmünde düzenlenmiş olup buna göre fiil ehliyetine sahip olanlar dava ehliyetine sahiptir.

Sınırlı ehliyetsizlerin yani ayırt etme gücüne sahip küçüklerin kural olarak dava ehliyetine sahip olmadığı ve davada ancak yasal temsilcileri tarafından temsil edilebileceği düşünülse de bazı hallerde örneğin kişi varlığı haklarını kullanırken sınırlı ehliyetsizlerin dava ehliyetinin olduğu kabul edilir ${ }^{25}$. Evlenmeye izin verilmesi talebi kişi varlığ 1 hakkına ilişkin bir hak olduğundan bu davada sınırlı ehliyetsizin dava ehliyetinin olduğu şüphesizdir.

Sınırlı ehliyetsiz, kişiye sıkı sıkıya bağlı haklarını kullanmaya kendisini karar verdikten sonra, iradi temsilci atayabilir. Bu durumda sınırlı ehliyetsizin evlenmeye izin talebi için avukatla yapacağı sözleşmenin, TMK m.16 anlamında borçlanma işlemi niteliğine haiz olması nedeniyle yasal temsilcinin rızasına bağlı olduğu unutulmamalıdır. Ancak sınırlı ehliyetsiz ivazsız bir avukatlık sözleşmesi yapıyorsa yasal temsilcinin rızasına bağlı olmadan bu sözleşmeyi yapabilecektir ${ }^{26}$.

\section{b. Küçüğün Ana/Babası veya Yasal Temsilcisi}

Evlenme izni bakımından küçük yerine yasal temsilcisi konumundaki ana ve babanın küçüğü temsilen evlenme izni talep etmesinin mümkün olmadığı kanımızca da isabetli şekilde doktrinde savunulmaktadır ${ }^{27}$. Önemle altını çizelim evlenme izni talep edecek tek kişi küçüğün kendisidir ve bu talepte yasal temsilcinin yeri yoktur. Dolayısıyla bu davanın, küçüğü temsilen yasal temsilci tarafindan ikame edilmesi mümkün değildir. Ancak ne yazık ki Yargıtay

\footnotetext{
${ }^{23}$ Ayrıca bkz. PEKCANITEZ, Hakan/ÖZEKES, Muhammet/AKKAN, Mine/TAŞ KORKMAZ, Hülya: Medenî Usûl Hukuku, İstanbul 2017, s.2107 vd; KURU, Baki/BUDAK, Ali Cem: "Hukuk Muhakemeleri Kanununun Getirdiği Başlıca Yenilikler”, İstanbul Barosu Dergisi, (5), 2011, s.33-34; Kanundaki açık düzenlemeye rağmen tespit hükmü niteliğinde olduğu yönünde bkz. TÜZÜNER, İKÜHFD 2012, s.20.

${ }^{24}$ RG. 18.1.2003/24997.

${ }^{25}$ PEKCANITEZ/ÖZEKES/AKKAN/TAŞ KORKMAZ, Cilt I, s.586; ELGÜN TOĞRUL, Emel Şeyda: Medenî Usûl Hukuku Bağlamında Dava Ehliyeti, Ankara Üniversitesi Sosyal Bilimler Enstitüsü Özel Hukuk Anabilim Dal1, Yayınlanmamış Doktora Tezi, Ankara 2019, s.160.

${ }_{26}$ İsviçre Federal Mahkemesi sınırlı ehliyetsizin kişiye sıkı sıkıya bağlı hakkın kullanılması için vekil tayin etme işleminde yasal temsilcinin rızasına ihtiyaç olmadığı, bu işlemin hakkın kullanılması kapsamında kaldığı yönünde sonuca varmıştır. BGer 5A_10/2007, http://www.servat.unibe.ch/dfr/bger/070323_5A_10-2007.html; Avukatlık sözleşmesi ivazlı olsa da yasal temsilcinin rızasına gerek olmadan yapılabileceği yönünde bkz. KURT, Ekrem: Türk Hukukunda Kişiye Sıkı Sıkıya Bağlı Haklar ve Sonuçları, İstanbul Kültür Üniversitesi Hukuk Fakültesi Dergisi, 15(2), 2016, s.128; KARAKAŞ, Fatma Tülay Kişiye Sıkı Sıkıya Bağlı Haklar, Ankara 2015, s.113.

${ }^{27}$ DURAL/ÖĞÜZ/GÜMÜŞ, N. 256; KURT, İKÜHFD 2016, s.145; KARAKAŞ, s.66; Aksi yönde bkz. TMK m.124/II anlamında evlenme izni talep etmek bakımından yasal temsilcinin izin veya katılımının gerekli olduğu yönünde AÇIKGÖZ, Aslı: Dar Anlamda Vesayeti Gerektiren Hâller ve Vesayet Altına Almanın İşlem Ehliyeti Bakımından Sonuçları, İstanbul 2017, s.274.
} 
kararlarının büyük çoğunluğunda evlenme izni talebi için mahkemeye küçüğün değil ana ve babasının başvurmuş olduğu görülmektedir. Hatta bir karardan anlaşılacağı üzere, yerel mahkeme yasal temsilci tarafindan yapılan evlenme izni başvurunda, evlenmesine izin verdiği küçüğü hiç dinlememiş, Yargıtay küçük dinlenilmeksizin evlenme izni veren mahkeme kararını bozmuştur ${ }^{28}$.

Bir başka kararında Yargıtay, evlenme izni davasında yasal temsilci ile küçüğün menfaatinin çatışıyor olmasından bahisle küçüğe kayyım atanması gerektiği yönünde karar oluşturmuştur $^{29}$. Bu karara katılmak mümkün değildir. Zira menfaat çatışması nedeniyle kayyım atanması, yasal temsilci ile küçügün menfaatinin çatıştığı hallerde ancak ve ancak yasal temsilcinin küçüğü temsil etmesinin mümkün olduğu hallerde söz konusu olabilir. Yasal temsilcinin zaten küçüğü temsil edemeyeceği hallerde kayyım atanmasına gerek yoktur.

Bilindiği üzere TMK m.16 uyarınca sınırlı ehliyetsizin kişiye sıkı sıkıya bağlı hakları kullanmasında yasal temsilcinin rızası gerekli değildir ve bu hakların kullanılmasına karar verme yetkisi sadece hak sahibindedir. Bu hakların kullanılmasında karar verme yetkisi ne yasal ne de iradî temsilciye bırakılabilir. Dolayısıyla ayırt etme gücüne sahip küçük veya kısıtlı bakımından kişiye sıkı sıkıya bağlı hakların kullanılması bakımından temsil düşmanlığı söz konusu olur ${ }^{30}$. Eş söylemle sınırlı ehliyetsiz, kişiye sıkı sıkıya bağlı haklarını kullanırken dava ehliyetine sahiptir. Ancak bazı durumlarda bu hakkın kullanılması için Kanun, yasal temsilcinin rızasını ya da işleme katılması gereğini düzenlemiş olabilir.

Belirtelim ki İsviçre Medeni Kanunu'nun 1 Ocak 2013 tarihinde yürürlüğe giren 19c maddesi gereği ayırt etme gücüne sahip sınırlı ehliyetsizin kanundaki istisnalar dışında kişiye sıkı sıkıya bağlı haklarını yasal temsilcinin rızasına bağlı olmadan tek başına kullanabileceği düzenlenmiştir. Dolayısıyla bu hukuk sisteminde ancak kanundaki açık hükmün varlığı halinde kişiye sıkı sıkıya bağlı hakkın kullanılması, sınırlı ehliyetsizin yasal temsilcisinin rızasına bağlanmıştır. Açık kanun hükmü olmayan tüm hallerde sınırlı ehliyetsiz, kişiye sıkı sıkıya bağlı hakkını tek başına kullanabilecektir.

Dolayısıyla İsviçre Hukuku'nda sınırlı ehliyetsiz bakımından bağımsız kullanılabilen kişiye sıkı sıkıya bağlı hak ve yasal temsilci rızası/katılımı ile kullanılabilen kişiye sıkı sıkıya bağ hak ayrımı yapılmaktadır¹. Bağımsız kullanılması mümkün kişiye sıkı sıkıya bağlı haklar bakımından, sınırlı ehliyetsizin dava ehliyeti vardır ve bu haklar sınırlı ehliyetsizin duygusal yaşamı ile sıkı ilişki içindeki haklardır.

Yasal temsilcinin rızasıyla kullanılabilen kişiye sıkı sıkıya bağlı haklar ise Kanun'un açık hükmü ile yasal temsilcinin rızasına bağlanmıştır ve bu hakların sınırlı ehliyetsiz tarafından tek başına kullanılması mümkün değildir. Nitekim bu Kanun'da açıkça yasal temsilci rızasına bağlanmış hakların yorum yoluyla genişletilmesi mümkün değildir. Örneğin nişanlanma bağımsız kişiye sıkı sıkıya bağlı hak iken, yasal temsilcinin rızasının olmadığı hallerde sınırlı ehliyetsizin sorumluluğunun söz konusu olmaması (İsMK m.90/II), çocuğun tanınması (İsMK m.260/II), miras sözleşmesi yapma (İsMK m.468/II) bu hukuk sisteminde yasal temsilcinin rizasına bağlanan kişiye sıkı sıkıya bağlı hak olarak düzenlenmiştir.

Diğer yandan İsviçre Hukuku'nda yapılan bir başka ayrım mutlak kişiye sıkı sıkıya bağlı ve nisbî kişiye sıkı sıkıya bağlı hak ayrımıdır ${ }^{32}$. İsMK m.19/c hükmünün ikinci fikrasında ayırt etme gücü olmayan kişilerin, kişiye sıkı sıkıya bağlı haklarının kullanılmasında kişiye çok sıkı bağlı hakların yasal temsilci tarafindan kullanılmasının mümkün olmadığı düzenlenmiştir. Dolayısıyla bu hukuk sisteminde mutlak kişiye sıkı sıkıya bağlı hakların yasal temsilci tarafindan

${ }^{28}$ Yargitay 2. HD, E. 1999/13645, K. 2000/1032, T. 2.2.2000E. 2004/3737, K. 2004/4675; 2. HD, T. 13.4.2004.

${ }^{29}$ Yargitay 2. HD, E. 1974/873, K. 1974/716, T. 18.2.1974; Kararın isabetli olduğu hakkında bkz. TÜZÜNER, İKÜHFD 2012, s.22.

${ }^{30}$ OĞUZMAN, Kemal/SELİÇİ, Özer/OKTAY ÖZDEMİR Saibe: Kişiler Hukuku (Gerçek ve Tüzel Kişiler), İstanbul 2020, N. 320; KARAKAŞ, s.36 vd.

31 BSK/BIGLER-EGGENBERGER/FANKHAUSER, Art. 19c, N.1; Ayrıca İsviçre Hukuku'ndaki diğer sınıflandırmalar için bkz. KARAKAŞ, s.61 vd.

$32 \mathrm{Bu}$ konuda bkz. OĞUZMAN/SELİÇİ/OKTAY ÖZDEMİR, N. 321 vd; BSK/BIGLEREGGENBERGER/FANKHAUSER, Art. 19c, N. 4; BREITSCHMID, Peter/JUNGO Alexandra (Heruasgeber): CHKHandkommentar zum Schweizer Privatrecht Personen- und Familienrecht Partnerschaftsgesetz, Art. 1-456 ZGB-PartG, Zürich 2016, Art. 19c, N. 1; TUOR, Peter/SCHNYDER, Bernhard/SCHMID, Jörg/RUMO-JUNGO, Alexandra: Das Schweizersche Zivilgesetzbuch, Zürich Basel Genf 2009, § 9, N. 44; KREN KOSTKIEWICZ, Jolanta/WOLF Stephan/AMSTUTZ, Marc/FANKHAUSER, Roland (Herausgeber): ZGB Kommentar Schweizerisches Zivilgesetzbuch, OFK-Orell Füssli Kommentar, Zürich 2016, Art. 19c, N. 4-7; BUCHER, Eugen/ AEBI-MULLER, Regina E.: Berner Kommentar, Schweizerisches Zivilgesetzbuch Die natürlichen Personen, Art. 11-19d ZGB, Bern 2017, Art. 19c, N. 239 vd. Ayrıca bkz. ELGÜN TOĞRUL, s.165 vd; KURT, İKÜHFD 2016, s.135 vd. 
kullanılması mümkün değilken; nisbî kişiye sıkı sıkıya bağlı hakların yasal temsilci tarafından kullanılması mümkün kılınmıştır. Ancak hükmün gerekçesinde hangi hakların mutlak, hangi hakların nisbî kişiye sıkı sıkıya bağlı hak olduğunun doktrin ve uygulama tarafından belirleneceği ifade edilmiştir ${ }^{33}$.

Özlüce, mutlak kişiye sıkı sıkıya bağlı hakların yasal temsilci tarafından kullanılması mümkün değildir. Nisbî kişiye sıkı sıkıya bağlı haklar bakımından ise yasal temsilcinin büyük oranda temsilen işlemi yapmasına izin verilmektedir. Doktrinde bu ayrımın hatalı olduğu, önemli olanın hak sahibinin hakkını tek başına kullanıp kullanmaması olduğu da belirtilmektedir ${ }^{34}$.

Konumuza dönecek olursak, ayırt etme gücüne sahip olmayan bir kişi için evlenme başvurusu yapılması mümkün olmayacağından bizim için önemli olan ayrım, bağımsız kişiye sıkı sıkıya bağlı hak ve yasal temsilci rızasına bağlı kişiye sıkı sıkıya bağlı hak ayrımıdır. Çünkü mutlak kişiye sıkı sıkıya bağlı hakkın bazı durumlarda Kanun tarafindan yasal temsilcinin izni/katılımı ile kullanılabileceği düzenlenmiş olabilir.

Evlenme izni talebi de bağımsız kişiye sıkı sıkıya bağlı hak niteliğinde olup bu hakkın bizzat ve sadece sınırlı ehliyetsiz tarafindan kullanılması gerekmektedir. Zaten mesele, aslında yasal temsilci aracılığı ile kullanılması mümkün olmayan bu hakkın sınırlı ehliyetsizi temsilen yasal temsilci tarafından kullanılmasıdır. TMK m.124/II'de yasal temsilcinin olanak varsa hâkim tarafından dinlenebileceği şeklinde düzenleme yapılmakla, yasal temsilcinin bu yargılamadaki konumu açıkça ortaya konulmuştur. Evlenme izni için sınırlı ehliyetsiz bizzat başvurmalı, yasal temsilcinin küçüğü temsilen açtığı dava ise red kararı ile sonuçlanmalıdır. Çünkü evlenme izin başvurusunun yasal temsilci tarafından yapılmasına imkân tanınması, sınırlı ehliyetsizin kişiye sıkı sıkıya bağlı hakkını kullanmayı bir başkasına devretmesi anlamına gelecektir.

\section{D. Şartlara Sahip Olmadan Evlenme İzni Verilmesi ve Buna Bağlı Sonuçlar}

\section{Genel Olarak}

Evlenmeye izin verilmesi şartları olmaksızın kişinin evlenmesine izin verilmişse, örneğin somut olayda olağanüstü sebep yoksa veya evlenmesine izin verilen kişi onaltı yaşını tamamlamışsa yine bu izne dayalı olarak kişi evlenmişse veyahut da onaltı yaşı doldurma şartını sağlamış ancak hâkimden izin almadan evlenmişse bu evliliğin akıbetinin ne olacağı irdelenmelidir ${ }^{35}$.

\section{Konuya İlişkin Tartışmalı Görüşler}

a. Yokluk Görüşü

Doktrinde ÖZTAN ${ }^{36}$ tarafindan savunulan ve Yargitay kararlarında rastlanan yokluk görüşüne göre, evlenemeye izin verilmesi şartları sağlanmaksızın evlilik yapılmışsa bu evlilik yok hükmündedir. Zira bu görüşe göre bu yaşın tamamlanmamış olması halinde yapılan evlenme, kurucu unsur eksikliği nedeniyle yok hükmündedir.

Yargıtay'ın bir kararında kişi, onaltı yaşını doldurma şartını sağlamadan örneğin onbeş yaşında evlenmiş olduğundan evliliğin yok hükmünde olduğu sonucuna varılmıştır. Yargıtay 2. HD, E. 2011/4235, K. 2011/7649, T. 3.05.2011 ${ }^{37}$ sayılı kararında aynen şu ifadeleri kullanmıştır: "Evleneceklerin evlenme yaşını (TMK m.124) doldurmuş olmaları, evlendirmeye salahiyetli memur önünde irade beyanı gibi geçerli bir evlenmenin asli ve kurucu unsurudur. Aktin kurucu unsurlarındaki noksanlık evlenmenin yokluğu sonucunu doğurur. Evlenme tarihinde davacı E, onbeş yaşını doldurmamış, hâkim tarafindan izin verilebilecek onaltı yaşını dahi tamamlamamıştır (TMK m.124 II). Bu durumda yapılan evlenme akdi, butlanla sakat değil, yok hükmünde olur (2.HD'nin 14.4.2003 tarihli 2003/4315-5370 sayll, 30.10.2006 tarihli 2006/6049-14441 Sayll kararları). Öyleyse evlenmenin yokluğunun tespitine karar verilmesi gerekirken, iptal hükmünün kurulması da usul ve yasaya aykırı olmuştur."

\footnotetext{
${ }^{33} \mathrm{https}: / /$ www.admin.ch/opc/de/federal-gazette/2006/7001.pdf.

${ }^{34}$ ZEVKLILER, s.304 vd; Hak sahibinin menfaatine göre her bir hak bakımından değerlendirme yapılması gerektiği yönünde AÇIKGÖZ, s.266; Türk Hukuku'nda bu ayrım için bkz. KARATAŞ, s.64 vd.

35 Tartışmalar için ayrıca bkz. KESKİN, Dilşad: “Küçük Yaşta Evlenmenin Müeyyidesi”, Gazi Üniversitesi Hukuk Fakültesi Dergisi, XV(4), 2011, 71 vd.

36 ÖZTAN, s.138.

${ }^{37}$ www.kazanci.com; Ayrıca bkz. benzer kararlar için Yargitay 2. HD, E. 2003/4315, K. 2003/5370, T. 14.04.2003

(Karar için bkz. KÖSEOĞLU, Bilal/ KOCAAĞA, Köksal: Aile Hukuku ve Uygulaması, Bursa 2011, s.9).
} 
Yine Yargitay 2. HD, E. 2000/7338, K. 2000/9756; T. 13.7.2000 sayılı kararına karş1 yazılan muhalefet şerhinde aynen şu ifadeler yer almaktadır: “...Kanun butlan hallerini açıkça belirlediğine göre, kanunda gösterilmeyenin dışında ki ehliyetsizliğin yaptırımının yokluk olması sebebiyle düzenlenmediğini kabul etmek zorunludur. Aksi hal kamu düzeni ile sikı sikıya ilişkili, evlenme ehliyetine dair yaş sının ile resmi memur huzurunda işlem şartının dolanılmasına imkân verir... Yok olan evliliğin Medeni Kanunun 118. maddesi uyarınca butlanı da söz konusu olamaz..."

\section{b. Butlan Görüşü}

Evlilik Hukuku'nda iki tür butlan söz konusu olup, evlenme izni şartları söz konusu olmadan evlenen kişi bakımından nisbî butlan ve mutlak butlan olmak üzere iki farklı görüş ileri sürülmektedir.

\section{i. Nisbî Butlan Görüşü}

$\mathrm{Bu}$ görüşe göre henüz evlenme yaşını tamamlamamış veya tamamlamakla birlikte yasal temsilci iznini almadan bir şekilde evlenmiş olan kişilerin evliliklerine ilişkin TMK m.153 hükmü, şartlar sağlanmadan gerçekleşen olağanüstü evlenmeler bakımından kıyasen uygulanmalıdır ${ }^{38}$. Nitekim TMK m.153 hükmü, yasal temsilci rızası olmaksızın kişinin evlenmesi halinde yasal temsilcinin nisbî butlan davası açabileceğini düzenlemektedir.

Doktrinde DURAL/ÖĞÜZ/GÜMÜŞ, onaltı yaşını doldurmuş olmak koşulu ile hâkimden izin almadan evlenmenin gerçekleştiği hallerde iki ihtimal olduğunu, evlenmenin geçerli sayılması gerektiğini ya da evlenmenin nisbî butlanla batıl sayılması gerektiğini, bu ihtimalde TMK m.153 hükmünün kıyasen uygulanmasının daha uygun olduğunu belirtmişlerdir ${ }^{39}$.

Evlenmenin nisbî butlan yaptırımına tabi olduğu kabul edilirse, örneğin 14 yaşında evlenen sınırlı ehliyetsizin durumundan haberdar olan üçüncü kişiler ve savcının dava açması mümkün olmayacağından, bu görüşün kabul edilmesi sakıncalıdır. Birçok ihtimalde yasal temsilci sınırlı ehliyetsizin evlenmesine ses çıkarmayacağından nisbî butlan, yasal temsilci tarafindan zaten ileri sürülmeyecektir.

Yine TMK m.153/II uyarınca bu yolla evlenen kişiler sonradan onsekiz yaşını doldurur veya kadın hamile kalırsa nisbî butlan ileri sürülemeyeceğinden, bu hükmün özellikle hâkim kararı olmadan evlenen onaltı yaşından küçükleri korumayacağı açıktır.

Yargitay 2. HD, E. 2006/6049, K. 2006/14441, T. 30.10.2006 sayılı kararında doğrudan olmasa da dolaylı olarak hâkimden izin almadan evlenmiş olan onaltı yaşını dolduran kişinin evliliğin butlanının savcı tarafından ileri sürülemeyeceği, dolayısıyla bu durumda nisbî butlanın söz konusu olduğu sonucuna varmıştır. Bu kararda aynen şu ifadeler kullanılmıştır: “... Cumhuriyet Başsavcılığının ... Hâkimden izin almaksızın evlendiği ileri sürerek evlenme akdinin ve nüfus kayttlarının iptaline karar verilmesinin talep edildiği, mahkemece davanın kabulüne karar verildiği ve hükmün temyiz edilmeksizin kesinleştiği anlaşılmaktadır. Bu davadaki olay mutlak butlan sebeplerinden olmadığından davayı Cumhuriyet Savcısı açamaz. O halde usulüne uygun açılmış olmayan davanın reddi gerekirken evliliğin iptaline karar verilmesi usul ve yasaya aykırıdır."

Bir başka kararında Mahkeme açıkça onaltı yaşını doldurup da hâkimden izin almadan evlenmenin nisbî butlan teșkil ettiği sonucuna varmıștır. Yargıtay 2. HD, E. 2007/17963, K. 2009/3892, T. 4.3.2009 say11 kararında “ ... Evlenenlerden davalı A., 01.06.1990 doğumlu olup, evlenme tarihinde 16 yaşını bitirmiştir. 16 yaşııı doldurmuş olan erkek veya kadın, ancak hâkimin evlenmeye izin vermesi halinde evlenebilir (TMK m.124/II). 16 yaşını doldurmuş olan kadın veya erkeğin hâkimin izni olmadan evlenmişs olmaları hali, nisbî butlan sebebi olup, $C$. Savcısının nisbî butlan nedeniyle evliliğin iptalini isteme yetkisi bulunmamaktadır. İsteğin reddi yerine kabulüne karar verilmesi doğru bulunmamıştır."

\section{ii. Mutlak Butlan Görüşü}

Evlenme izni olmaksızın evlenen kişinin evliliğinin mutlak butlan yaptırıma tâbi olduğunu savunan görüş kendi içinde iki farklı gerekçe ile savunulmaktadır.

Öne sürülen bir gerekçeye göre; evlenme yaşına gelmeyen kişi, özellikle onaltı yaşını doldurmamış kişi, bir şekilde evlenmişse bu evlilik mutlak butlanla batıldır zira kişi bu yönde hak

\footnotetext{
${ }^{38}$ VELİDEDEOĞLU, s.58, s.282; TEKİNAY, s.158,159; AKINTÜRK/KARAMAN, s.225.

${ }^{39}$ DURAL/ÖĞÜZ/GÜMÜŞ, N. 278; Benzer şekilde AÇIKGÖZ, s.279.
} 
ehliyetine sahip değildir ve bu konuda ayrıca düzenleme yapılmasına gerek dahi yoktur ${ }^{40}$. Bu evlilik bakımından mutlak butlana ilişkin hükümler uygulama alanı bulur.

Diğer gerekçeye göre; küçük yaşta evlenen kişinin evlenme bakımından ayırt etme gücü yoktur, ayırt etme gücünün yokluğu da Kanun'da mutlak butlan sebebi (TMK m.145) olarak düzenlenmiş olduğundan bu konuda ayrıca düzenlemeye gerek olmaksızın evlenmenin mutlak butlanı söz konusu olur ${ }^{41}$. Kanunda bazı hallerde kişinin belirli bir yaşı tamamlaması gereken haller sayılmış olup bu yaşın tamamlanmadığı hallerde o işlemi yapmak bakımından kişinin ayırt etme gücüne sahip olmadığ faraziyesi düzenlenmiştir. Dolayısıyla belirlenen yaşın altında yapılan evlenme bakımından kişinin ayırt etme gücüne sahip olmadığı, evlenmenin mutlak butlanla batıl olduğu kabul edilmelidir.

Olağanüstü evlenme yaşı bakımından aynı kural geçerli olmalıdır. Kanun onyedi yaşındaki kişinin evlenme bakımından ayırt etme gücüne sahip olduğunu faraziye olarak kabul etmiş ancak onaltı yaşını dolduran bakımından bu faraziyeyi kabul etmemiştir ${ }^{42}$. Dolayısıyla evlenme izni verecek hâkimin diğer şartların yanında kişinin bu yönde ayırt gücü olup olmadığını da takdir etmesi gerekir. Eğer şart sağlanmamasına rağmen kişiye evlenme izni verilmiş ya da izin olmadan kişi evlenmişse evlilik mutlan butlanla batıldır. Evlilik mutlak butlanla batıl olunca, bu evliliğin mutlak butlanı ilgili herkes tarafından ve savcı tarafından dava edilebilecektir.

\section{Konuya İlişkin Görüşümüz}

Evlenme izin şartları olmaksızın yapılmış evliliği yok hükmünde kabul etmek mümkün değildir. Zira bu ihtimalde miras ve soybağı sorunları gündeme gelecek ve Evlilik Hukuku'nun hükümsüzlük rejimi devre dışı bırakılarak sınırlı ehliyetsizin korunması amacından uzaklaşılacaktır.

Bu evliliğe nisbî butlan sonucu bağlamak da kanımızca sakıncalıdır. Zira bu ihtimalde savcının dava açma hakkı söz konusu olmayacağından bu görüşün benimsenmesi küçüğün korunması amacından uzaklaşılması sonucunu doğuracaktır.

Kanımızca konu hakkından mutlak butlan görüşünün benimsenmesi gerekir. Kanun'da mutlak ve nisbî butlan sebepleri sınırlı sayıda düzenlenmiş olsa da faraziye olarak kişinin onyedi yaşını tamamlamakla evlenme bakımından ayırt etme gücüne sahip olduğu düzenlenmiştir. Dolayısıyla onyedi yaşını tamamlamayan kişiler bakımından ayırt etme gücünün yokluğu nedeniyle evliliğin mutlak butlanla batıl olduğunun kabul edilmesi, küçüğün korunması amacına en fazla hizmet eden görüştür.

Nitekim İsviçre Medeni Kanunu'nda, 1 Haziran 2013'de yürürlüğe giren değişiklikle mutlak butlanın düzenlendiği m.105 hükmüne 6 . bent eklenmek suretiyle tarafların onsekiz yaşının altında olmasını mutlak butlan sebebi (süresiz geçersizlik) olarak düzenlenmiştir ${ }^{43}$. Bu hüküm, kişilerin bu yaşın altında olmaları halinde evlenme bakımından ayırt etme gücüne sahip olmayacakları kabulüne dayanmaktadır. Ancak hükümde, evlenme yaşına gelmeden yapılmış olan evliliklerin mutlak butlan yaptırımına tabi olduğu düzenlenmiş olsa da, evliliğin devamı küçügün üstün menfaatlerine uygun düşüyorsa mutlak butlanın söz konusu olmayacağı da düzenlenmiştir. Özellikle butlan kararı yerine eşler bakımından boşanma kararı daha elverişli olacaksa ya da evlilik zaten ölümle sona ermişse butlan kararına gerek olmadığı belirtilmektedir ${ }^{44}$.

\section{E. Korunması Gereken Menfaat Temelinde İstinaf/Temyiz Hakkı Olanlar}

Çekişmesiz yarg1 işlerine ilişkin kararlara karşı yargı yolunu düzenleyen HMK m.387 uyarınca çekişmesiz yargı işlerinde verilen kararlara karşı hukukî yararı bulunan ilgililer, özel kanunî düzenlemeler saklı kalmak kaydıyla, kararın öğrenilmesinden itibaren iki hafta içinde, Kanun hükümleri dairesinde istinaf yoluna başvurabilirler.

\footnotetext{
${ }^{40}$ DURAL/ÖĞÜZ/GÜMÜŞ, N. 278; KESKİN, GÜHFD 2011, s.81-82.

${ }^{41}$ VELIDEDEOĞLU, s.249.

${ }^{42}$ Kanunda ayırt etme gücü karinesi yaratılmış olduğunu, her somut olayda hâkimin evlenme bakımından ayırt etme gücünün olup olmadığını araştırması gerektiği, kadın ve erkek bakımından 15 yaşın tamamlanmasının sınır olarak Kanun'da düzenlenmesinin mümkün olduğu yönünde bkz. HATEMİ, § 4, N. 9-11.

${ }^{43}$ Belirtelim ki bu değişikliği takip edecek şekilde İsviçre'de Uluslararası Özel Hukuk Kanunu m.44 hükmünde kişinin milli hukukundan aksine bir düzenleme olsa bile onsekiz yaşının altındaki evlenmeler tamamen yasaklanmıştır. BSKMONTINI/GRAF-GAISER, Art. 94, N. 2.

${ }^{44}$ BSK-GEISER, Art. 105, N. 22-23; CHK-KELLER, Art. 105, N. 8; Ayrıca bkz. HAVUTÇU, Ayşe: "Mukayeseli Hukuktaki Gelişmeler Işığında Türk Medeni Kanunu Açısından Zorla Evlenme Probleminin Değerlendirmesi”, Journal of Yasar University, 8(Özel Say1), 2013, s.1373.
} 
$\mathrm{Bu}$ noktada savcılığın istinafa başvurup başvuramayacağı üzerine düşünülmeli ve başvurabileceği sonucuna varılmalıdır. Zira bilindiği üzere savcı Kamu Hukukunun süjesi olmasına rağmen Aile Hukuku'nda ilişkin bazı işlemlerde yetkili ve görevli kişidir. Zaten evliliğin mutlak butlanı davası açmaya yetkili olan savcının, evlenme izni kararına karşı evleviyetle istinaf yoluna başvurması mümkün kabul edilmelidir.

Çalışma konumuz bakımından aslında küçük tarafından talepte bulunulması gereken evlenme izninin yasal temsilci tarafından da talep edilmesine izin verilince, şartların oluşmadığ hallerde hukukî yararı bulunan ve istinaf hükümlerine başvuran kişiden bahsetmek pek de mümkün olmayacaktır. Elbette onaltı yaşını tamamlamış olan küçüğün evlenme izni talep ettiği hallerde, yasal temsilcinin evlenme izni kararına karşı istinaf yoluna başvurması mümkündür.

$\mathrm{Bu}$ durumda özellikle onaltı yaş şartı sağlanmamasına rağmen -ki 2015 öncesi birçok kararda bu şart sağlanmadan yerel mahkemelerin evlenme izni verdiği gözlemlenmekle- yerel mahkeme evlenmeye izin verecek olursa ve bu karar için istinaf yoluna başvurulmazsa HMK m.363 hükmünden başka yol kalmayacaktır. 'Kanun Yararına Temyiz' başlıklı bu hüküm uyarınca: "İlk derece mahkemelerinin kesin olarak verdikleri kararlar ile istinaf incelemesinden geçmeden kesinleşmiş bulunan kararlarına ve bölge adliye mahkemesi hukuk dairelerinin ilk derece mahkemesi sifatiyla kesin olarak verdikleri kararlar ile yine bu sifatla verdikleri ve temyiz incelemesinden geçmeden kesinleşmiş bulunan kararlarına karşı, yürürlükteki hukuka aykırı bulunduğu ileri sürülerek Adalet Bakanlığl veya Yargitay Cumhuriyet Başsavcıllı̆g tarafindan kanun yararına temyiz yoluna başvurulur."

Görüldüğü üzere bu hüküm uyarınca, yerel mahkemenin evlenmeye izin kararına karş1 Adalet Bakanlığı'nın veya Cumhuriyet Başsavcılığının kanun yararına temyiz yoluna başvurması mümkündür. Şu hususun altını çizmek gerekir ki Yargıtay tarafindan Adalet Bakanlığı'nın kanun yararına temyiz başvurusu ile bozulan ve ulaştığımız son karar 2015 yılına aittir. Yaptığımız araştırmalarda 2015 yılından sonra kanun yararına bozulan kararlara neden rastlanmadığı bilgisine ise ulaşılamamıştır. Umarız bunun sebebi Adalet Bakanlığı'nın kanun yararına temyiz talep etmemesi değil de iyimser bir beklenti ile Yerel Mahkemelerin konuda hakkında doğru kararlar vermesidir.

\section{TMK m.124/II HÜKMÜNE GERÇEKTEN İHTIYAÇ VAR MI?}

Çalışmamızın yapılma amacı TMK m.124/II hükmünün yürürlükten kaldırılması gereğine işaret etmektir. Buraya kadar yaptığımız değerlendirme gösteriyor ki özellikle kız çocukları için onaltı yaşını dahi tamamlamadan evlenme izni için başvurular yapılmakta, bu başvurular yasal temsilci tarafindan yapılmakta, kanuna yararına temyiz kurumu işletilmeyince şartları sağlamayan kişilerin yaptı̆̆ evlilikler geçerli bir evlilik olarak varlığını sürdürmektedir. Anayasa ${ }^{45}$ ve Uluslararası Mevzuata baktığımız zaman özellikle çocuğun korunması bakımından devletlere büyük görevler düştüğünü görmekteyiz.

Anayasa m.41/II, III aynen "Devlet, ailenin huzur ve refahı ile özellikle ananın ve çocukların korunması ve aile planlamasının öğretimi ile uygulanmasını sağlamak için gerekli tedbirleri alır, teşkilatı kurar. Devlet, her türlü istismara ve şiddete karşı çocukları koruyucu tedbirleri alınır" şeklindedir.

Kadına Karşı Her Türlü Ayrımcılığın Önlenmesi Sözleşmesi (CEDAW) ${ }^{46}$ m.16 gereği devletlerin çocuğun erken yaşta evlenmesi veya nişanlanmasını yasal saymaması gerektiğine işaret eder.

İnsan Hakları Evrensel Beyannamesinin ${ }^{47}$ 16. maddesi evlenme sözleşmesinin evleneceklerin tam ve özgür iradesine dayanması gerektiğine işaret eder.

Birleşmiş Milletler Çocuk Hakları Sözleşmesine ${ }^{48}$ göre onsekiz yaşını doldurana kadar herkes çocuktur.

\footnotetext{
${ }^{45}$ RG. 9.11.1982/17863

${ }^{46} \mathrm{Bu}$ sözleşme Bakanlar Kurulunun 24.07.1985 tarihli kararı ile onaylamış ve 14.10.1985 tarihli resmi gazetede yayınlanmıştır.

47 Beyanname Baklanlar Kurulunun 6.4.1949 tarihli kararıyla onaylanmış ve 27.5.1949 tarihli resmi gazetede yayınlanmıştır.

${ }^{48} \mathrm{Bu}$ sözleşme Bakanlar Kurulunun 23.12.1994 tarihli kararı ile onaylanmış ve 27.1.1995 tarihli resmi gazetede yayınlanmıştır.
} 
Kadına Yönelik Şiddet ve Aile İçi Şiddetin Önlenmesi ve Bunlarla Mücadeleye Dair Avrupa Konseyi Sözleşmesi ${ }^{49}$ m.37 uyarınca devletler çocuğu kasten evliliğe zorlamanın cezalandırılmasını temin etmek üzere gerekli yasal veya diğer tedbirleri alma yükümlügü altına girmişlerdir ${ }^{50}$.

Çocukların Cinsel Suiistimale ve Cinsel İstismara Karşı Korunmasına İlişkin Avrupa Konseyi Sözleşmesi ${ }^{51}$ taraf devletlerin çocuğa karşı her türlü istismar ve sömürüyü engellemek için tedbirleri almak zorunda olduğunu düzenlemektedir.

Tüm bu metinler göstermektedir ki hem onyedi yaşında yasal temsilci rıasılyla hem de onaltı yaşında hâkim izni ile evlenmeyi mümkün kılan TMK m.124 hükmünün hem birinci hem de ikinci fikrası aslında Anayasa'ya ve Türkiye'nin taraf olduğu uluslararası sözleşmelere aykırıdır ${ }^{52} / 5^{53}$ ve yürürlükten kaldırılmalıdır.

Nitekim TMK m.124 hükmünün iptali için Ankara 10. Asliye Hukuk Mahkemesi somut norm denetimi başvurusunda bulunmuş olmasına rağmen Anayasa Mahkemesi 2016/126 E, 2016/119 K, 22.6.2016 tarihli kararında, somut olayda TMK m.124/II hükmünün uygulama olanağı olmadığından Mahkemenin yetkisizliği nedeniyle davanın reddine karar vermiştir. Dolayısıyla Anayasa Mahkemesi bu kararında TMK m.124/II'nin Anayasaya ve uluslararas1 anlaşmalara uygun olduğu kanaatine varmış değildir.

Ancak TMK m.124 hükmü yürürlükten kaldırılana kadar en azından şartların sağlanmaması halinde yapılan evliliğin akıbetinin mutlak butlan olduğu kabul edilerek ilgili herkesin mutlak butlan davası açmasına izin verilmelidir. Diğer yandan şartları değerlendiren hâkim gerçekten de çok istisnai hallerde evlenme izni vermeli, çocuğun hamile kalmış olması, kadın ve erkeğin birlikte yaşaması asla evlenme izni için yeterli saymamalıdır.

Evlenme izni bakımından 'evlenme olgunluğuna erişme' asla zorunlu şart olarak kabul edilmemeli, tüm şartlar mevcut olsa ve tıp bilimi kişinin evlenme olgunluğuna erişmiş olduğu kanısına varmış olsa dahi hâkim 'çocuğun üstün menfaati' ilkesine üstünlük vermelidir.

Yine evlenme izni başvurusunun mutlak kişiye sıkı sıkıya bağlı hak niteliğinde olduğu nazara alınarak yasal temsilcinin küçüğü temsilen ikame ettiği davalar mahkemeler tarafından reddedilmelidir.

Son olarak 2015 yilından bu yana Yargitay kararlarında rastlanmayan ya da bu yönde karar olmakla birlikte tarafımızca ulaşılmayan, Adalet Bakanlığı veya Cumhuriyet Başsavcılığı tarafından yapılması mümkün olan kanun yararına temyiz taleplerine tekrardan rastlanması en büyük temennimizdir.

\footnotetext{
$49 \mathrm{Bu}$ sözleşme Bakanlar Kurulunun 10.2.2012 tarihli kararı ile onaylanmış ve 8.3.2012 tarihli resmi gazetede yayınlanmıştır.

50 Sözleşmenin getirdiği izleme mekanizmasına göre (m.66); sözleşmenin etkili bir şekilde uygulanmasını sağlamak üzere, Avrupa Konseyi bünyesinde, 10 ila 15 uzmanın yer aldığı 'Kadına Yönelik ve Aile İçi Şiddete Karşı Mücadelede Uzmanlar Grubu' (GREVIO) adlı bir denetim mekanizması oluşturulmuştur. GREVIO'nun görevi, taraf devletler hakkında düzenli denetim raporları hazırlamak, raporlarda üye devletlere önerilerde bulunmak, bu önerilerin yerine getirildiği getirilmediğini takip etmek, Avrupa genelinde kadın-erkek eşitliği ve kadına yönelik şiddetle mücadelede ortak normlar yaratılmasına ve taraf devletlerde bu alanlarda ilerleme sağlanmasına ortam yaratmaktır. Nitekim GREVIO, Türkiye için ilk değerlendirme raporunu 15 Ekim 2018 tarihinde açılamıştır (https://ailevecalisma.gov.tr/media/3825/grevio-rapor-turkce-5bd99d7dbb799.pdf). Bu raporda yer alan bilgilere göre Türkiye'de kadınların \%25'inden fazlası 18 yaşından önce evlenmekte, bu oran kırsal alanda \%32'ye yükselmektedir. Bu kadınların \%19,9'u bir aile kararıyla rızası olmadan evlendiğini belirtirken, bu evliliklerin \%46,8'inin aile kararı içerdiği, vakıaların \% 45 'inden fazlasında, reşit olmayan kızın kendinden 5 ila 9 yaş büyük bir erkekle evlendiği ve bu vakaların \%23'ünden fazlasında yaş farkının 10 ya da daha fazla olduğu, küçük bir kız çocuğuyla yapılan evliliklerin yaklaşık beşte birinde başlık parası ödendiği, bu evliliklerin \%13'ünde kızların yaşı hakkında yalan söylendiği bilgileri yer almaktadır. Ancak üzülerek söylemek gerekir ki bu ayrıntılı raporda TMK m.124/II hükmünün yürürlükten kaldırılması gereğine hiç işaret edilmemiş, aksine TMK'da zorla evliliğin yaptırımının doğrudan düzenlenmemiş olduğu gibi bir tespit edilmiştir.

51 Bu sözleşme Bakanlar Kurulu'nun 18.7.2011 sayılı kararı ile onaylanmıș ve 10.9.2011 tarihli resmi gazetede yayınlanmıştır.

52 Ayrıca bkz. NAMLI, GÜHFD 2003, s.258; SUNGURTEKİN ÖZKAN, Yasar 2013, s.2180 vd; HAVUTÇU, Yaşar 2013, s.1379; TÜZÜNER, İKÜHFD 2012, s.24-25; REYHANİ YÜKSEL, Hukuk ve Adalet 2015, s.36 vd.

${ }^{53}$ Evlenme yaşının kadın ve erkek için onsekiz yaşına çıkarılması için yine olağanüstü evlenmeye ilişkin düzenlemenin yürürlükten kaldırılması için bu zamana kadar çeşitli tarihlerde kanun teklifleri verilmiş olsa da bu teklifler reddedilmiştir. Bu çalışmanın yapıldığı sırada hem olağan hem de olağanüstü evlenme yaşına ilişkin durumu itibari ile Komisyonda bekleyen 1.10.2018 ve 1.10.2019 tarihli iki Kanun teklifi bulunmaktadır.

https://www.tbmm.gov.tr/develop/owa/tasari_teklif_sd.sorgu_baslangic (ET: 8.10.2020).
} 


\section{V.SONUÇ}

Çocuğun evlenmesine mümkün k1lan TMK m.124/II hükmünün yürürlükten kaldırılmas1 gerektiği şüphesizdir. Hüküm yürürlükten kaldırılana kadar çocuğun üstün menfaatine üstünlük verilmesi ve hükmün uygulanma alanın dar tutulması hukuku uygulayanların elindedir. Kanun yararına bozma ile 2015 yılına kadar Yargıtay'ın önüne gelen olaylarda evlenmesine izin verilmesi istenen hep k1z çocuğudur ve yerel mahkemeler şartlar oluşmadan evlenmeye izin kararları vermiştir. Onsekiz yaşın dahi evlenme için yeterli olup olmadığı tartışılması gerekirken 2020 dünyasında onaltı yaşındaki çocuğun evlenmesine izin vermek kabul edilemez sonuçlara gebedir. En kısa sürede hükmün yürürlükten kaldırılması veya Anayasa aykırılığının iddia edilmesi en büyük temennimizdir.

\section{KAYNAKÇA}

AÇIKGÖZ, Aslı: Dar Anlamda Vesayeti Gerektiren Hâller ve Vesayet Altına Almanın İşlem Ehliyeti Bakımından Sonuçları, İstanbul 2017.

AKINTÜRK, Turgut/ATEŞ KARAMAN, Derya: Türk Medenî Hukuku, Aile Hukuku, II. Cilt, İstanbul 2020.

BREITSCHMID, Peter/RUMO-JUNGO, Alexandra (Heruasgeber): CHK-Handkommentar zum Schweizer Privatrecht Personen- und Familienrecht Partnerschaftsgesetz Art. 1-456 ZGB, PartG, Zürich 2016 (CHK-İşleyen).

BUCHER, Eugen/AEBI-MULLER, Regina E.: Berner Kommentar, Schweizerisches Zivilgesetzbuch, Die natürlichen Personen, Art. 11-19d ZGB, Bern 2017 (BK-İ̀sleyen).

DURAL, Mustafa/ÖĞÜZ, Tufan: Türk Özel Hukuku, Cilt II: Kişiler Hukuku, İstanbul 2019.

DURAL, Mustafa/ÖĞÜZ, Tufan/GÜMÜŞ, Mustafa Alper: Türk Özel Hukuku, Cilt III: Aile Hukuku, İstanbul 2020.

ELGÜN TOĞRUL, Emel Şeyda: Medenî Usûl Hukuku Bağlamında Dava Ehliyeti, Ankara Üniversitesi Sosyal Bilimler Enstitüsü Özel Hukuk Anabilim Dalı, Yayınlanmamış Doktora Tezi, Ankara 2019.

FEYZİOĞLU, Feyzi: Aile Hukuku, İstanbul 1986.

HATEMI, Hüseyin: Aile Hukuku, İstanbul 2020.

HAVUTÇU, Ayşe: "Mukayeseli Hukuktaki Gelişmeler Işığında Türk Medeni Kanunu Açısından Zorla Evlenme Probleminin Değerlendirmesi”, Journal of Yasar University, 8 (Özel Sayı), 2013, s.1341-1382 (HAVUTÇU, Yaşar 2013).

HEINRICH, Honsell/VOGT, Nedim Peter/GEISER, Thomas (Herausgeber): Basler Kommentar, Zivivlgezetzbuch I, Art. 1-456, Michel Montini/Cora Graf-Gaiser (Bearbeiter), Basel 2014 (BSK-İşleyen).

KARAKAŞ, Fatma Tülay: Kişiye Sıkı Sıkıya Bağlı Haklar, Ankara 2015.

KESKIN, Dilşad "Küçük Yaşta Evlenmenin Müeyyidesi”, Gazi Üniversitesi Hukuk Fakültesi Dergisi, XV(4), 2011, s.65-83 (KESKIN, GÜHFD 2011).

KILIÇOĞLU, Ahmet: Aile Hukuku, Ankara 2019.

KREN KOSTKIEWICZ, Jolanta/WOLF, Stephan/AMSTUTZ, Marc/FANKHAUSER, Roland (Herausgeber): ZGB Kommentar Schweizerisches Zivilgesetzbuc OFK Orell Füssli Kommentar, Zürich 2016 (OFK-İsleyen).

KÖSEOĞLU, Bilal/ KOCAAĞA, Köksal: Aile Hukuku ve Uygulaması, Bursa 2011.

KURT, Ekrem: Türk Hukukunda Kişiye Sıkı Sıkıya Bağlı Haklar ve Sonuçları, İstanbul Kültür Üniversitesi Hukuk Fakültesi Dergisi, 15(2), 2016, s.121-187 (KURT, İKÜHFD 2016).

KURU, Baki/BUDAK, Ali Cem: "Hukuk Muhakemeleri Kanununun Getirdiği Başlıca Yenilikler", İstanbul Barosu Dergisi, 5, 2011, s.3-43 (KURU/BUDAK, İBD 2011).

NAMLI, Mert: "Yeni Medenî Kanunun Evlilik Hukukunda Yaptığı Değişiklikler", Galatasaray Üniversitesi Hukuk Fakültesi Dergisi, 2(2), 2003, s.241-388 (NAMLI, GÜHFD 2003).

OĞUZMAN, Kemal/SELİÇİ, Özer/OKTAY ÖZDEMİR, Saibe: Kişiler Hukuku (Gerçek ve Tüzel Kişiler), İstanbul 2020.

ÖZTAN, Bilge: Aile Hukuku, Ankara 2015.

REYHANI YÜKSEL, Sera: “Türk Medenî Kanunu'ndaki Evlenme Yaşına İlişkin Düzenlemenin Çocuk Hakları Açısından Değerlendirilmesi”, Hukuk ve Adalet Dergisi, 7(17), 2015, s.2142 (Reyhani Yüksel, Hukuk ve Adalet 2015).

PEKCANITEZ, Hakan/ÖZEKES, Muhammet/AKKAN, Mine/TAŞ KORKMAZ, Hülya: Medenî Usûl Hukuku, Cilt I, İstanbul 2017.

SAYMEN, Ferit Hakkı/ELBİR, Halid Kemal: Türk Medenî Hukuku, C. III, Aile Hukuku, İstanbul 1960.

SCHWARZ, Andreas: Aile Hukuku, Çev. Bülent Davran, İstanbul 1946. 
SUNGURTEKIN ÖZKAN, Meral: "Erken Yaşta Evliliklerin Önlenmesi Konusunda Yargının Üstlenebileceği Rol”, Journal of Yasar University, 8(Özel Say1), 2013, s.2177-2188 (SUNGURTEKIN ÖZKAN, Yaşar 2013).

TEKİNAY, Selahattin Sulhi: Türk Aile Hukuku, İstanbul 1982.

TUOR, Peter/SCHNYDER, Bernhard/SCHMID, Jörg/RUMO-JUNGO Alexandra: Das Schweizersche Zivilgesetzbuch, Zürich Basel Genf 2009.

TÜZÜNER, Özlem: “Onaltı Yaşını Doldurmuş Kişinin Evlenmesine İzin Verilmesi”, İstanbul Kültür Üniversitesi Hukuk Fakültesi Dergisi, (11), 2012, s.7-29 (TÜZÜNER, İKÜHFD 2012).

VELİDEDEOĞLU, Hıfzı Veldet: Türk Medenî Hukuku, C. II, Aile Hukuku, İstanbul 1965.

YÜCEL, Özge: “Çocuğun Yüksek (Üstün) yararı Bağlamında Çocuğun İradesi”, Ufuk Üniversitesi Hukuk Fakültesi Dergisi, (3), 2013, s.117-137 (YÜCEL, UÜHFD 2013).

ZEVKLİLER, Aydın: Giriş ve Başlangıç Hükümleri, Kişiler Hukuku, Aile Hukuku, Ankara 1992. 